\title{
Artikel
}

\section{Heimelijke toepassing van openlijke bevoegdheden}

Prof. mr. T. Blom*

\section{Inleiding}

In het nieuwe Wetboek van Strafvordering (Sv) wordt voorgesteld om in meer gevallen dan op basis van onze huidige wet opsporingsbevoegdheden te introduceren die normaal gesproken openlijk worden toegepast maar nu (ook) heimelijk kunnen worden toegepast, terwijl deze bevoegdheden niet in Boek 2 in het hoofdstuk dat gaat over heimelijke bevoegdheden (hoofdstuk 8) worden opgenomen.

In dit artikel wordt een uiteenzetting gegeven welke bevoegdheden het betreft, waarom ze worden geïntroduceerd en wat de reden is waarom deze bevoegdheden (ook) heimelijk zouden moeten kunnen worden ingezet. Nagegaan zal worden of deze bevoegdheden een inbreuk maken op rechten die zijn gegarandeerd in het EVRM en of de voorgestelde wettelijke regeling een toereikende basis biedt voor de rechtvaardiging daarvan. Voornaamste focus daarbij is het recht op privacy van burgers (art. 8) en het recht op een 'effectieve remedy' (art. 13) indien van een schending sprake is. Tot slot zal de wenselijkheid van de codificatie van deze heimelijke bevoegdheden worden beoordeeld.

Het betreft feitelijk twee situatie waarin de 'nieuwe' bevoegdheden mogen worden ingezet. In de eerste situatie is er sprake van de heimelijk toepassing van de bevoegdheid waarbij het niet de bedoeling is dat de verdachte op de hoogte raakt van de toepassing van die bevoegdheid. Vooral deze situatie is in deze bijdrage van belang. De tweede situatie betreft de omstandigheid dat

Prof. mr. T. (Tom) Blom is hoogleraar Straf(proces)recht aan de Universiteit van Amsterdam. de verdachte niet op de hoogte is van de toepassing van de 'nieuwe' bevoegdheden omdat hij weigert mee te werken of niet te traceren valt (vermist is). Strikt genomen hoeft er in dit geval geen sprake te zijn van een heimelijke toepassing van de bevoegdheid maar slechts van een andere wijze van onderzoek waarbij de inzet of de aanwezigheid van de verdachte wordt vermeden. Deze situatie zal hieronder slechts worden besproken indien dat noodzakelijk is voor een beter begrip van de bevoegdheid.

De uiteenzetting zal worden begonnen met een korte beschrijving van de bevoegdheden. Daarbij zal de volgorde van de voorgestelde wettelijke regeling worden aangehouden.

\section{De bevoegdheden}

De bevoegdheden die in het nieuwe wetboek worden voorgesteld en waarvan de toepassing ook heimelijk moet kunnen plaatsvinden zijn: vergelijkend vingerafdruk en handpalmonderzoek (art. 2.6.5.4.2), handschrift- en stemvergelijkend onderzoek (art. 2.6.5.5.1), inbeslagneming van voorwerpen en de inzet van daartoe strekkende steunbevoegdheden (art. 2.7.2.1.3), het bij gelegenheid van een doorzoeking of betreding van een plaats overnemen van gegevens (art. 2.7.3.1.1) en het bevel tot verstrekking van gegevens (art. 2.7.3.1.2). Alleen het handschrift- en stemvergelijkend onderzoek bevat een nieuwe (in de wet geregelde) bevoegdheid. De andere reeds bestaande bevoegdheden mogen in de toekomst ook heimelijk worden ingezet.

Overigens is het ook heimelijk mogen toepassen van openlijke bevoegdheden geen nieuw fenomeen. De hui- 
dige wet kent deze mogelijkheid al bij DNA-onderzoek. ${ }^{1}$ Artikel 151b lid 4 Sv heeft dan ook model gestaan voor de wettelijke regeling van het vergelijkend vingerafdruk en handpalmonderzoek en het handschrift- en stemvergelijkend onderzoek. ${ }^{2}$ Anders dan in het huidige artikel $151 \mathrm{~b}$ lid $4 \mathrm{~Sv}$ is er echter voor gekozen om de drie gevallen waarin de bevoegdheden mogen worden gebruikt zonder dat de verdachte daar weet van heeft, expliciet te benoemen. Dat zijn de situaties waarin de verdachte zich tegen het onderzoek verzet, vermist is of het in het belang van het onderzoek is dat de verdachte niet op de hoogte rakt van het tegen hem lopend onderzoek. Slechts de laatste is in deze bijdrage van belang.

\subsection{Vergelijkend vingerafdrukken en handpalmonderzoek}

Artikel 2.6.5.4.2

3. In afwijking van het eerste lid kan de officier van justitie, indien het in het belang van het onderzoek is dat de vingerafdrukken of handpalmafdrukken van de verdachte buiten zijn medeweten worden verkregen, of indien de verdachte zich tegen de afname van zijn vingerafdrukken of handpalmafdrukken verzet of vermist is, het vergelijkend onderzoek laten verrichten aan de vingerafdrukken of handpalmafdrukken die op een in beslag genomen voorwerp aanwezig zijn of op andere wijze verkregen zijn, mits voldoende zekerheid bestaat dat die vingerafdrukken of handpalmafdrukken van hem afkomstig zijn.

4. Indien de vingerafdrukken of handpalmafdrukken buiten medeweten van de verdachte zijn verkregen en ten behoeve van een vergelijkend onderzoek zijn gebruikt, stelt de officier van justitie hem, zodra het belang van het onderzoek dat toelaat, daarvan en van de uitslag van het vergelijkend onderzoek schriftelijk in kennis.

Het nieuwe art. 2.6.5.4.2 lid 3 maakt een uitzondering op de regel dat vingerafdrukken en handpalmafdrukken van de verdachte zelf worden afgenomen voor vergelijkend onderzoek. De officier van justitie kan, indien het in het belang van het onderzoek is dat vingerafdrukken of handpalmafdrukken van de verdachte buiten zijn medeweten worden verkregen het vergelijkend onderzoek laten verrichten aan vingerafdrukken of handpalmafdrukken die op een in beslag genomen voorwerp aanwezig zijn of op andere wijze zijn verkregen. Of het in het belang van het onderzoek is, is afhankelijk van de afweging van belangen. Zoals in dit geval het recht op privacy van de verdachte ten opzichte van het belang van het opsporingsonderzoek van een strafbaar feit waar vier jaar of meer op staat. Het betreft een afweging van

1. Het huidige art. 151b lid 4 Sv geeft de officier van justitie de mogelijkheid om 'indien zich naar het oordeel van de officier van justitie zwaarwegende redenen voordoen' het DNA-onderzoek aan ander celmateriaal te laten plaatsvinden

2. Vaststellingswet Boek 2 van het nieuwe Wetboek van Strafvordering: Het opsporingsonderzoek, memorie van toelichting, p. 146-147 en 150. Te vinden op www.rijksoverheid.nl/documenten/publicaties/2017/ 11/13/documenten-. proportionaliteit en subsidiariteit. In de memorie van toelichting bij dit artikel wordt als voorbeeld van de heimelijke bevoegdheid gegeven dat de officier van justitie voor het vergelijkend onderzoek de vingerafdrukken of handpalmafdrukken gebruikt die zijn achtergebleven op een inbeslaggenomen voorwerp zoals een koffiekopje. ${ }^{3}$ Voorwaarde is wel dat er voldoende zekerheid moet bestaan dat die vingerafdrukken of handpalmafdrukken inderdaad van de verdachte afkomstig zijn. Het criterium 'in het belang van het onderzoek' is ook van belang bij het bepalen van het moment dat onderzoeksresultaten wel aan betrokkenen moet worden afgegeven. Zodra het belang van het onderzoek dat toelaat moet de verdachte door de officier van justitie schriftelijk in kennis worden gesteld van het feit dat het hier bedoelde onderzoek heeft plaatsgehad en wat de uitslag van dit onderzoek was (art. 2.6.5.4.2 lid 4). Gesteld wordt dat de opsporingspraktijk behoefte heeft aan deze bevoegdheid kennelijk vooral indien op basis van feiten en omstandigheden duidelijk is dat de dader binnen een bepaalde groep moet worden gezocht en het tevens belangrijk is dat wordt voorkomen dat de andere leden van die groep daarvan op de hoogte raken. ${ }^{4}$

\subsection{Handschriftvergelijkend en stemvergelijkend onderzoek}

Artikel 2.6.5.5.1

1. In geval van verdenking van een misdrijf waarop naar de wettelijke omschrijving gevangenisstraf van twee jaar of meer is gesteld, kan de officier van justitie of de hulpofficier van justitie bevelen dat de opsporingsambtenaar de verdachte:

a. een tekst laat opschrijven ten behoeve van een handschriftvergelijkend onderzoek;

b. een tekst laat uitspreken ten behoeve van een stemvergelijkend onderzoek of een confrontatie (...).

2. In afwijking van het eerste lid kan de officier van justitie, indien het in het belang van het onderzoek is dat het handschriftvergelijkend of stemvergelijkend onderzoek buiten medeweten van de verdachte wordt verricht, of indien de verdachte niet aan de onderzoekshandeling, bedoeld in het eerste lid, onderdeel $a$ of $b$, meewerkt of vermist is, het onderzoek laten verrichten aan het handschrift dat of de stem die op een in beslag genomen voorwerp aanwezig is of op andere wijze verkregen is, mits voldoende zekerheid bestaat dat dat handschrift of die stem van hem afkomstig is.

3. Indien het handschriftvergelijkend of stemvergelijkend onderzoek buiten medeweten van de verdachte is verricht, stelt de officier van justitie hem, zodra het belang van het onderzoek dat toelaat, daarvan en van de uitslag van het vergelijkend onderzoek schriftelijk in kennis.

In artikel 2.6.5.5.1 wordt een nieuwe bevoegdheid geïntroduceerd: het onderzoek ten aanzien van fysieke

3. Vaststellingswet Boek 2, MvT, p. 146

4. Vaststellingswet Boek 2, MvT, p. 147 
eigenschappen zoals handschriftonderzoek en stemvergelijkend onderzoek. Dergelijke onderzoeken worden al enige tijd als instrument in het opsporingsonderzoek gebruikt en krijgen in het nieuwe wetboek een specifiek wettelijke basis en dus ook een nadere normering. De huidige toepassing is gebaseerd op vrijwilligheid maar omdat er in de praktijk verdachten zijn die niet vrijwillig die handelingen willen verrichten, kan deze medewerking in de toekomst worden bevolen.

Handschriftvergelijkend onderzoek vindt op dit moment vooral toepassing bij onderzoek naar fraude, afpersing en bedreiging waar het zijn waarde heeft bewezen. ${ }^{5}$ In de memorie van toelichting wordt gerefereerd aan zaken waarbij door de vergelijking van de handtekening van de verdachte met de handtekening op een vervalste factuur of van zijn handschrift met het handschrift op een dreigbrief kon worden bepaald dat het van dezelfde persoon afkomstig was.

Op dezelfde wijze zou de door de verdachte ingesproken tekst kunnen worden vergeleken met de opgenomen stem van een drugsdealer of overvaller. Als dat zo is, zou dat als bewijs kunnen worden gebruikt in de strafzaak tegen de verdachte. ${ }^{6}$ In de memorie van toelichting wordt met geen woord gerept over de betrouwbaarheid van de methode en de waarde daarvan voor het bewijs. De beoordeling daarvan wordt kennelijk geheel overgelaten aan de rechter.

In de nieuwe bevoegdheid wordt geregeld dat in geval van verdenking van een misdrijf waarop naar de wettelijke omschrijving gevangenisstraf van twee jaar of meer is gesteld de (hulp)officier van justitie kan bevelen dat een opsporingsambtenaar de verdachte een tekst laat op schrijven of laat uitspreken ten behoeve van een vergelijkend handschrift- of stemonderzoek. Deze nieuwe bevoegdheid mag op bevel van de officier van justitie ook heimelijk plaatsvinden als dat in belang is van het onderzoek. Ook hier geldt dus dat er een afweging wordt gemaakt tussen de belangen van de verdachte en het belang van de opsporing van misdrijven waarop twee jaar of meer gevangenisstraf is gesteld. Bovendien geldt als voorwaarde dat er voldoende zekerheid moet zijn dat het handschrift of de stem daadwerkelijk van de verdachte afkomstig is en dat zodra het belang van het onderzoek dat toelaat de verdachte schriftelijk in kennis wordt gesteld van de toepassing van de bevoegdheid en de resultaten van het onderzoek.

\subsection{Inbeslagneming van voorwerpen}

Artikel 2.7.2.1.3 (bewijs van uitoefening inbeslagneming en mogelijkheid tot uitstel)

1. In geval van inbeslagneming wordt direct een bewijs van uitoefening van deze bevoegdheid afgegeven aan de beslagene of achtergelaten op de plaats van inbeslagneming. Dit bewijs bevat een aanduiding van de inbeslaggenomen voorwerpen.

2. De officier van justitie kan, indien het belang van het onderzoek dit dringend vereist, bevelen dat het

5. Vaststellingswet Boek 2, MvT, p. 149

6. Vaststellingswet Boek 2, MvT, p. 149. afgeven of achterlaten van dit bewijs wordt uitgesteld. Dit bevel tot uitstel kan alleen worden gehandhaafd na een daartoe verleende machtiging van de rechter-commissaris, die zo spoedig mogelijk door de officier van justitie wordt gevorderd. $\mathrm{Na}$ verleende machtiging van de rechter-commissaris wordt het bewijs afgegeven of achtergelaten zodra het belang van het onderzoek dit toelaat.

In het nieuwe artikel 2.7.2.1.3 is de mogelijkheid van heimelijke toepassing op iets andere wijze vormgegeven dan in de hiervoor besproken regelingen. Lid 1 schept (net als het huidige art. 94 lid $3 \mathrm{~Sv}$ ) de verplichting om in geval van inbeslagneming direct een bewijs van uitoefening van deze bevoegdheid af te geven aan de beslagene of achter te laten op de plaats van inbeslagneming. ${ }^{7}$ Het doel van het achterlaten van het bewijs is het informeren van de beslagene. Op deze wijze raakt de beslagene op de hoogte van de inbreuk op zijn beschikkingsmacht en (mogelijk) eigendomsrecht en kan hij daartegen - als hij dat wenst - in rechte opkomen. Lid 2 geeft de officier van justitie echter de mogelijkheid om indien het belang van het onderzoek dit dringend vereist te bevelen dat het afgeven of achterlaten van dit bewijs wordt uitgesteld. Dat mag slechts indien de rechtercommissaris daartoe een machtiging verleent en het bewijs van inbeslagneming alsnog wordt afgegeven of achtergelaten zodra het belang van het onderzoek dit toelaat. In de memorie van toelichting wordt als voorbeeld van een dringend onderzoeksbelang de situatie geschetst dat bij de inbeslagneming van gevaarlijke en/of schadelijke voorwerpen (die vervolgens worden vervangen door (daarop lijkende) ongevaarlijke of onschadelijke voorwerpen) het dringende onderzoeksbelang uitstel van afgifte rechtvaardigt zodat het opsporingsonderzoek ongehinderd kan worden voortgezet. ${ }^{8}$ In het nieuwe artikel 2.7.2.2.12 wordt bovendien geregeld dat indien de steunbevoegdheden betreden van plaatsen of doorzoeking zijn toegepast om inbeslagneming mogelijk te maken en zijn uitgeoefend buiten de aanwezigheid van de rechthebbende van de desbetreffende plaats, vervoermiddel of woning de officier van justitie - ook ingeval geen voorwerpen in beslag zijn genomen kan bevelen dat de achterlating van de kennisgeving wordt uitgesteld. Indien het de rechter-commissaris is die de bevoegdheid heeft toegepast, komt deze bevoegdheid aan hem toe. Uitstel mag ook hier slechts plaatsvinden indien het belang van het onderzoek dit dringend vordert en de kennisgeving zal moeten worden afgegeven aan de rechthebbende of bewoner zodra het belang van het onderzoek dit toelaat. Het betreft in dit artikel dus de situatie dat de betreding of doorzoeking niet heeft geleid tot de inbeslagneming van voorwerpen.

7. De verplichting tot kennisgeving is in de huidige regeling wel iets ruimer geformuleerd: 'Zoveel mogelijk wordt aan degene bij wie een voorwerp is inbeslaggenomen, een bewijs van ontvangst afgegeven'. Ook spreekt de huidige regeling niet van 'direct'

8. Conceptwetsvoorstel en MvT Boek 2, onderdeel 'Inbeslagneming van voorwerpen met uitstel van verstrekking van het bewijs van uitoefening van de bevoegdheid tot inbeslagneming', p. 4. 
Het (voorlopig) geheim houden van de inbeslagneming wordt noodzakelijk geacht in situaties waarbij inbeslaggenomen gevaarlijke of schadelijke voorwerpen worden vervangen door ongevaarlijke of onschadelijke voorwerpen, zodat het opsporingsonderzoek ongehinderd kan worden voortgezet. De memorie van toelichting geeft als voorbeeld een onderzoek naar een gewapende overval waarbij tien bolletjes drugs in beslag worden genomen, onder vervanging door een op verdovende middelen gelijkend poeder. Door de drugs te vervangen door onschadelijke middelen en de beslagenen daar niet direct van op de hoogte stellen, kan het opsporingsonderzoek met betrekking tot de verdachten worden voorgezet. Volgens de memorie van toelichting kan ook gedacht worden aan liquidatie(voorbereidings)zaken.

'Een belangrijk onderdeel van de voorbereiding van een liquidatie is het zogeheten "koud stellen" van gestolen auto's die worden voorzien van valse kentekenplaten. Als de politie stuit op zo'n auto en daarin voorwerpen aantreft die gebruikt kunnen worden bij de liquidatie (denk aan wapens en jerrycans gevuld met benzine), kan vanuit opsporingsbelang de dringende behoefte bestaan om die voorwerpen in beslag te nemen en te vervangen door soortgelijke, maar niet functionerende voorwerpen. De beslagene hoeft ook in deze gevallen niet direct op de hoogte te worden gesteld van de inbeslagneming. Op die manier kan het opsporingsonderzoek worden voortgezet om te achterhalen wie de uiteindelijke daders en de beoogde slachtoffers zijn.'

\subsection{Overnemen van gegevens}

Artikel 2.7.3.1.1

1. In geval tijdens een doorzoeking of betreding als bedoeld in deze titel gegevens worden overgenomen, wordt direct een bewijs van uitoefening van deze bevoegdheid afgegeven aan degene bij wie de gegevens zijn overgenomen, of achtergelaten op de plaats die is betreden of doorzocht. Dit bewijs bevat de aard van de overgenomen gegevens.

(...)

3. De officier van justitie kan, indien het belang van het onderzoek dit dringend vereist, bevelen dat het afgeven of achterlaten van het bewijs wordt uitgesteld. Dit bevel tot uitstel kan alleen worden gehandhaafd na een daartoe verleende machtiging van de rechter-commissaris, die zo spoedig mogelijk door de officier van justitie wordt gevorderd. $\mathrm{Na}$ verleende machtiging van de rechter-commissaris wordt het bewijs afgegeven of achtergelaten zodra het belang van het onderzoek dit toelaat.

Onder onderzoek van gegevens wordt verstaan het geheel aan handelingen dat wordt verricht met betrekking tot gegevens. Ook de handelingen in of aan gegevensdragers of geautomatiseerde werken die betrekking hebben op de daarin opgeslagen gegevens worden gezien als onderzoek van gegevens. Indien tijdens een doorzoeking of betreding gegevens zijn overgenomen, dient een bewijs te worden afgegeven aan degene bij wie de gegevens zijn overgenomen of worden achtergelaten op de plaats die is betreden of doorzocht om de gegevens over te kunnen nemen. Uit het bewijs dat moet worden afgegeven of achtergelaten moet blijken dat er op de desbetreffende plaats onderzoek van gegevens heeft plaatsgevonden en dat dit heeft geleid tot het overnemen van gegevens. Het afgeven van het bewijs is beperkt tot betredings- en doorzoekingssituaties.

Ook bij het onderzoek van gegevens wordt de mogelijkheid gecreëerd om onderzoek mogelijk te maken zonder dat de verdachte daarvan op de hoogte raakt - en dus heimelijk kan worden ingezet - indien het belang van het onderzoek dit dringend vereist. Ook hier geldt dat de rechter-commissaris daartoe een machtiging moet verlenen en het bewijs van uitoefening moet worden afgegeven (of achtergelaten) zodra het belang van het onderzoek dit toelaat.

\subsection{Bevel tot verstrekking van gegevens}

Artikel 2.7.3.1.2

Degene die anders dan voor persoonlijk gebruik gegevens verwerkt en

a. bij wie een betreding of een doorzoeking plaatsvindt voor het verrichten van onderzoek van gegevens;

b. tot wie een bevel als bedoeld in artikel 2.7.3.2.7, eerste lid, is gericht;

c. tot wie een bevel als bedoeld in Afdeling 7.3.3 is gericht, neemt in het belang van het onderzoek geheimhouding in acht over datgene wat hem met betrekking tot die betreding of doorzoeking of dat bevel bekend is.

De reeds in artikel $126 \mathrm{bb}$ lid $5 \mathrm{~Sv}$ bestaande verplichting tot geheimhouding wordt uitgebreid naar alle vorderingen gegevens te verstrekken (in de nieuwe terminologie van het wetboek 'bevelen' genoemd). ${ }^{10}$ Bovendien wordt in de nieuwe regeling geheimhouding opgelegd aan degene bij wie een betreding of doorzoeking plaatsvindt om een onderzoek van gegevens uit te voeren. Die geheimhoudingplicht is op grond van de huidige wetgeving niet mogelijk terwijl daarbij dezelfde belangen een rol kunnen spelen als bij een bevel tot verstrekking van die gegevens, namelijk dat het in het belang van het onderzoek kan zijn dat de verdachte waarop het opsporingsonderzoek zich richt daarvan voorlopig niet op de hoogte raakt. De voorgestelde regeling beperkt zich tot 'degene die anders dan voor persoonlijk gebruik gegevens verwerkt'. Daarmee is een probleem in de huidige regeling verholpen. De geheimhoudingsplicht geldt op dit moment ook voor personen die in een vriendschappelijke of familiaire verhouding 
tot elkaar staan, terwijl dat nooit de bedoeling van de wetgever is geweest. ${ }^{11}$

\section{Recht op privacy (art. 8 EVRM)}

De vraag is of alle hiervoor beschreven bevoegdheden een inbreuk maken op het recht op privacy van burgers en of een dergelijke inbreuk uiteindelijk ook een schending van artikel $8 \mathrm{EVRM}$ oplevert. Een inbreuk die 'in accordance with the law' is, 'necessary in a democratic society' is en een 'legitimate aim' dient levert immers geen schending van artikel 8 EVRM op.

Het EHRM heeft nooit getracht om een definitie van privacy te geven omdat dat volgens het Hof onmogelijk en onnodig is. ${ }^{12}$ Het Hof beperkt zich ertoe van geval tot geval te bepalen of er sprake is van een inbreuk op het recht op privacy. Uit de analyse van deze jurisprudentie kan wel worden afgeleid dat het recht betrekking heeft op het streven van het individu om zijn leven in vrijheid naar zijn zin in te richten en om in dit (persoonlijk) leven gevrijwaard te blijven van ongewenste inmenging, vooral van de kant van de overheid. ${ }^{13}$ De wetgever heeft bij de introductie van de bijzondere opsporingsbevoegdheden in 1996 (in het nieuwe wetboek 'heimelijke bevoegdheden' genoemd) aangegeven dat deze bevoegdheden een inbreuk maken op het recht op privacy van de verdachte indien de toepassing 'een min of meer volledig beeld van bepaalde aspecten van iemands privéleven' oplevert. ${ }^{14}$

De opslag van gegevens die tot een persoon herleidbaar zijn in databanken vormt een inbreuk op het recht op privacy van burgers. ${ }^{15}$ Het vergelijkend vingerafdrukken- en handpalmonderzoek (art. 2.6.5.4.2) maakt alleen daarom al een inbreuk op artikel 8 EVRM. Datzelfde zal gaan gelden voor het handschrift- en stemvergelijkend onderzoek (art. 2.6.5.5.1) indien deze worden opgeslagen in een databank, maar ook los daarvan is het een vergelijkend onderzoek waarvan het resultaat herleidbaar is tot en gelieerd is aan een bepaald persoon - in een vorm die het mogelijk maakt die persoon te identificeren. Als zodanig raakt dat dus zijn privacy. Het bevel

11. Conceptwetsvoorstel Boek 2 van het nieuwe Wetboek van Strafvordering, onderdeel 'Opsporing in een digitale omgeving' (7 februari 2019), MvT, p. 7.

12. EHRM 16 december 1992, appl.nr. 13710/88, Series A, no. 251-B, par. 29 (Niemietz/Duitsland).

13. Zie T. Blom, 'Privacy, EVRM en (straf)rechtshandhaving', in: C.H. Brants, P.A.M. Mevis \& E. Prakken (red.), Legitieme strafvordering, Antwerpen/Groningen: Intersentia 2001, p. 122 en de daarin aangehaalde jurisprudentie en de Guide on Article 8 of the European Convention on Human Rights, 2019, p. 20 (www.echr.coe.int/ Documents/Guide_8_ENG.pdf).

14. Kamerstukken II 1996/97, 25403, nr. 3, p. 7. De MvT gaf twee voorbeelden: het uitgavenpatroon van een verdachte of diens contacten met een crimineel.

15. Zie EHRM 26 maart 1987, appl.nr. 9248/81, Series A, no. 116, par. 48 (Leander/Zweden), EHRM 16 februari 2000, appl.nr. 27798/95, ECHR 2000-II, par. 69 en 80 (Amann/Zwitzerland) en EHRM 4 mei 2000, appl.nr. 28341/95, ECHR 2000-V, par. 46 (Rotaru/Romania). uitleveren van gegevens (art. 2.7.3.1.4), het overnemen van gegevens (art. 2.7.3.1.1) en de inbeslagneming van voorwerpen (art. 2.7.2.1.3) hebben betrekking op gegevens en voorwerpen die over de verdachte gaan of van de verdachte (afkomstig) zijn en dus een inbreuk op zijn privacy vormen. Indien de laatste twee bevoegdheden plaatsvinden in een woning is ook het huisrecht geschonden. Bovendien zullen deze gegevens ook worden opgeslagen in (tijdelijke) gegevensbestanden.

3.1 In accordance with the law

De beoordeling of de inbreuk die deze bevoegdheden maken 'in accordance with the law' is, valt uiteen in een aantal vragen: heeft de inbreuk een basis in het nationale recht, voldoet dat recht aan het vereiste 'accessibility' en aan de 'rule of law', in verband met de 'foreseeability'. De burger moet op basis van deze wettelijke regeling een duidelijke indicatie krijgen onder welke voorwaarden er door opsporingsambtenaren een inbreuk mag worden gemaakt op dit recht.

De wettelijke regeling die voorziet in een inbreuk op dit recht moet volgens het EHRM voldoen aan bepaalde kwaliteitseisen. ${ }^{16}$ Dat zorgt er niet alleen voor dat burgers worden beschermd tegen willekeurige toepassing maar ook dat burgers worden geinformeerd over de voorwaarden waaronder een dergelijke inbreuk mag worden gemaakt. Dit geldt in bijzondere mate indien de bevoegdheden in het geheim of althans buiten medeweten van betrokkene worden uitgeoefend en dus de kans op willekeur groot is. ${ }^{17}$ Die kwaliteitseisen houden onder andere in: een duidelijke omschrijving van de bevoegdheid; de categorie personen die eraan kunnen worden onderworpen; de gevallen; de gronden; proportionaliteits- en subsidiariteitseisen; de wijze waarop de bevoegdheid wordt gevorderd en opgedragen; de autoriteit die de bevoegdheid beveelt, uitvoert en er toezicht op uitoefent. ${ }^{18}$

Omdat (ook) bij deze bevoegdheden - die immers heimelijk worden toegepast - het gevaar bestaat dat misbruik ervan (in potentie) eenvoudig is, vindt het Hof het wenselijk - maar dus niet noodzakelijk - dat toezicht op de uitvoering van de bevoegdheid in handen is van een rechter omdat dit de beste garantie is voor een onafhankelijk en onpartijdig onderzoek. ${ }^{19}$

De hiervoor beschreven bevoegdheden voldoen aan alle voorwaarden. Ze zijn op een heldere wijze omschreven en op duidelijke wijze wordt aangegeven wie het mag

16. Zie bijv. EHRM 25 juni 1997, appl.nr. 20605/92, Report of Judgments and Decisions 1997-III, par. 49 (Halford/Verenigd Koninkrijk), EHRM 25 maart 1983, appl.nr. 5947/72 e.v., Series A, no. 61, par. 87 (Silver e.a./Verenigd Koninkrijk) en EHRM 21 juni 2011, appl.nr. 30194/09, par. 68 (Shimovolos/Rusland).

17. EHRM 2 augustus 1984, appl.nr. 8691/79, Series A, no. 82, par. 67 (Malone/Verenigd Koninkrijk).

18. Zie T. Blom, Drugs in het recht, recht onder druk, Deel 3, Arnhem: Gouda Quint 1998, p. 156-163 en de (voornaamste) uitspraken van het EHRM: Malone/Verenigd Koninkrijk, par. 68, Leander/Zweden, par 51, EHRM 24 april 1990, appl.nr. 11105/84, Series A, no. 176-B, par 33-34 (Huvig/Frankrijk), Amann/Zwitzerland, par. 56-58 en EHRM 4 december 2015, appl.nr. 47143/06, ECHR 2015, par. 231 (Roman Zakharov/ Rusland).

19. Roman Zakharov/Rusland, par. 232. 
betreffen, ${ }^{20}$ wie het bevel tot toepassing of uitstel geeft, ${ }^{21}$ wie het bevel uitvoert en wie er toezicht houdt op de uitoefening ervan. Slechts bij de bevoegdheden van artikel 2.7.2.1.3 (inbeslagneming van voorwerpen) en artikel 2.7.3.1.1 (overnemen van gegevens) wordt bij de heimelijke toepassing nadrukkelijk bepaald dat het bevel tot uitstel (van het achterlaten van de kennisgeving van de uitoefening van de bevoegdheid) slechts mag worden verleend na een daartoe verleende machtiging van de rechter-commissaris. De rechter-commissaris heeft dus geen toezichthoudende taak bij de andere bevoegdheden. Daar staat echter tegenover dat bij deze bevoegdheden het gevaar voor misbruik wordt bestreden door de eis dat er voldoende zekerheid moet bestaan dat de vingerafdrukken of handpalmafdrukken, het handschrift en de stem voor vergelijkend onderzoek daadwerkelijk van de verdachte afkomstig zijn. Bij de geheimhouding van artikel 2.7.3.1.4 speelt het gevaar van misbruik niet en bestaat er dus ook geen noodzaak om de rechter-commissaris met het toezicht te belasten.

\section{2 'Legitimate aim' en 'necessary in a democratic society'}

Het legitieme doel dat met de heimelijke toepassing van deze bevoegdheden wordt gediend is de opsporing en vervolging van strafbare feiten en levert in het licht van artikel 8 EVRM geen probleem op.

Dat deze bevoegdheden ook nodig zijn in onze samenleving ('necessary in a democratic society') ter bestrijding van (ernstige vormen van) criminaliteit wordt in de memorie van toelichting meer dan aannemelijk gemaakt. Deze toets valt - als we kijken naar de jurisprudentie van het Europese Hof - uiteen in een drietal criteria: voor de inmenging moet een dringende maatschappelijk behoefte bestaan ('pressing social need'), de inbreuk moet evenredig zijn aan het nagestreefde doel ('proportionate') en de redenen die worden gegeven om een dergelijke inbreuk mogelijk te maken, moeten 'relevant and sufficient' zijn in het licht van het te bereiken doel. ${ }^{22}$ Bovendien geldt bij de 'necessary'-toets een ruime 'margin of appreciation'. ${ }^{23}$

In de memorie van toelichting worden voor de introductie van de heimelijke toepassing van de bevoegdheden voorbeelden gegeven waaruit het (dringende maatschappelijke) belang kan worden afgeleid. In paragraaf 2.1 is

20. Voor het vingerafdruk en handpalmafdruk vergelijkend onderzoek geldt het zgn. vierjaarscriterium. Handschrift en stemvergelijkend onderzoek mogen al plaatsvinden indien er sprake is van een misdrijf waarop twee jaar of meer gevangenisstraf is gesteld. Terwijl de andere bevoegdheden aansluiten bij de voorwaarden die gelden voor de toepassing van de hulpbevoegdheden binnentreding ter inbeslagneming en doorzoeking ter inbeslagneming.

21. Bij alle hier bedoelde bevoegdheden is dat ten minste de officier van justitie.

22. Guide on Article 8 of the European Convention on Human Rights, p. 12. Dit zijn echter geen cumulatieve voorwaarden. In EHRM 24 november 1986, appl.nr. 9063/80, Series A, no. 109, par. 56 en 58 (Gillow/Verenigd Koninkrijk) en EHRM 30 maart 1989, appl.nr. 10461/83, Series A, no. 152-A, par. 60, 62-66 (Chappell/Verenigd Koninkrijk), werd slechts getoetst aan het proportionaliteitsvereiste.

23. EHRM 22 oktober 1981, appl.nr. 7525/76, Series A, no. 45, par. 52 (Dudgeon/Verenigd Koninkrijk) al het voorbeeld gegeven van vingerafdruk- en/of handpalmafdrukvergelijkend onderzoek aan de hand van een (achtergebleven) koffiekopje. Als dringend belang wordt geschetst de situatie dat de dader van een ernstig misdrijf binnen een bepaalde groep moet worden gezocht en dat tevens belangrijk is te voorkomen dat de leden van deze groep worden geinformeerd over het opsporingsonderzoek en anderszins worden beïnloed. ${ }^{24} \mathrm{Met}$ betrekking tot het handschrift en stemvergelijkend onderzoek wordt aangegeven dat het handschriftonderzoek zich bewezen heeft als waardevol instrument bij de bestrijding van fraude, afpersing en bedreiging. Ook met de al in paragraaf 2.1 behandelde voorbeelden uit de memorie van toelichting waarin het belang van het voorlopig geheim houden van inbeslaggenomen voorwerpen wordt aangetoond, wordt een breder maatschappelijk belang aangegeven naast een specifiek opsporingsbelang. Op basis van het voorgaande kan worden gesteld dat de wettelijke regeling voldoet aan alle kwaliteitseisen die aan de toepassing van dergelijke bevoegdheden moeten worden gesteld, wordt er een legitiem doel gediend en wordt ook de noodzaak voor invoering van de heimelijke toepassing aangetoond. Het zal uiteindelijk van de praktijktoets ('necessary') afhangen of ook bij de concrete toepassing voldaan wordt aan de in de wet vereiste afweging van belangen en of de inzet op zorgvuldige wijze volgens de wettelijke regeling heeft plaatsgevonden.

\section{Inbreuk op artikel 13 EVRM}

De bevoegdheden waarvan nu de heimelijke toepassing wordt overwogen worden in beginsel openlijk toegepast. Dat lijkt ook logisch omdat bijvoorbeeld bij de inbeslagneming de beslagene meestal aanwezig is als er in beslag genomen wordt. Bij de heimelijke toepassing raakt de betrokkene pas door het (later) afgeven of achterlaten van het bewijs van uitvoering op de hoogte van de inbeslagname (of van de betreding of doorzoeking). De verplichting tot het afgegeven of achterlaten van het bewijs van uitvoering is een uitvloeisel van het recht dat is gegarandeerd in artikel 13 EVRM. Artikel 13 garandeert dat een ieder wiens rechten en vrijheden neergelegd in het EVRM zijn geschonden recht heeft op een 'effective remedy before a national authority'. Uitstel van deze verplichting mag dus niet leiden tot afstel.

Bij vier van de beschreven bevoegdheden wordt terecht voorgeschreven dat zodra het belang van het onderzoek het toelaat (en dat mag enige tijd duren maar in ieder geval voor aanvang van de zitting) de verdachte, beslagene of degene bij wie de gegevens zijn overgenomen schriftelijk op de hoogte wordt gesteld van het feit dat een dergelijke bevoegdheid is toegepast. ${ }^{25}$ Het bevel tot

24. Vaststellingswet Boek 2 van het nieuwe Wetboek van Strafvordering: Het opsporingsonderzoek, MvT, p. 147.

25. Bij de vijfde bevoegdheid speelt deze problematiek niet omdat die geen betrekking heeft op de verdachte maar op degene die anders dan voor persoonlijk gebruik gegevens verwerkt en bij wie een betreding of een 
uitstel als bedoeld in artikel 2.7.2.1.3 en 2.7.3.1.1 mag bovendien alleen worden gehandhaafd na een daartoe verleende machtiging van de rechter-commissaris. De tussenkomst van de rechter-commissaris bij een beslissing tot uitstel is daar dus verplicht. In samenhang met de geschetste notificatieverplichting zorgt dat ervoor dat schending van artikel 13 EVRM niet aan de orde is.

\section{Tot slot}

De vraag die overblijft, is of het ook wenselijk is dat deze bevoegdheden in de toekomst ook heimelijk mogen worden toegepast. Op basis van het voorgaande kan worden gesteld dat een wettelijke regeling van de heimelijke toepassing van deze bevoegdheden noodzakelijk en ook wenselijk is. Het voordeel van codificatie is bovendien dat - waar het nu vaak gaat om een ongeregelde praktijk - door codificatie duidelijk wordt onder wiens gezag de toepassing van een dergelijke bevoegdheid valt en wat de kwaliteitseisen (geval, grond, enz.) zijn waaraan voldaan moet zijn voordat de bevoegdheid mag worden toegepast zodat willekeurige toepassing wordt vermeden. Bovendien kunnen de toepassingsvoorwaarden worden afgestemd op al wel geregelde bevoegdheden van vergelijkbare zwaarte. Het vergelijkend onderzoek van vingerafdrukken of handpalmafdrukken is daar een goed voorbeeld van. NRC meldde al in 2001 deze kennelijk gangbare praktijk van de politie. ${ }^{26}$

Codificatie en dus normering van een dergelijke praktijk is dan angewezen en de afstemming met de wettelijke regeling van het DNA-onderzoek logisch. Ook bij vergelijkend handschrift- en stemonderzoek lijkt sprake te zijn van een al bestaande praktijk die nu echter op vrijwilligheid is gebaseerd. Het probleem daarbij is dat bepaalde verdachten weigeren an een dergelijke opdracht vrijwillig te voldoen. Dat wordt in de praktijk als probleem ervaren, vandaar dat er een bevoegdheid komt. De heimelijke toepassing van deze bevoegdheid staat of valt echter met de zekerheid dat het te vergelijken handschrift en de te vergelijken stem inderdaad van de verdachte afkomstig is. Die zekerheid is bij een heimelijke toepassing niet gegarandeerd en dus onderwerp van debat. Het is bovendien aan de rechter om te beoordelen of het resultaat van het onderzoek waarbij een overeenkomst wordt vastgesteld ook voldoende betrouwbaar is en kan bijdragen aan het wettig bewijs en de daarop gebaseerde rechterlijke overtuiging en aldus kan leiden tot een veroordeling. Onderzoekers van het

doorzoeking ter inbeslagneming van gegevens plaatsvindt of tot wie een bevel als bedoeld in afdeling 7.3.3 is gericht.

26. 'Op de koffie', NRC 5 maart 2001. Volgens het artikel had de politie iemand - die nog niet officieel als verdachte in een moordzaak was aangemerkt, maar tegen wie wel verdenkingen bestonden - uitgenodigd voor enkele vragen over het slachtoffer. Tijdens het gesprek kreeg hij koffie aangeboden. Het speeksel op het kopje werd vervolgens verzameld en met toestemming van de rechter-commissaris naar het NFI gestuurd. Dit krantenartikel leidde tot Kamervragen van Dittrich (D66) en een beantwoording door minister van Justitie Korthals, Aanhangsel Handelingen // 2000/01, nr. 981
NFI zullen hun bevindingen met betrekking tot vergelijkend handschriftonderzoek weergeven in waarschijnlijkheidstermen. ${ }^{27}$ Het is aan de rechter om die bevindingen te waarderen. Rechters hebben bij de waardering van de bewijskracht van stemherkenning met enige regelmaat geoordeeld dat behoedzaamheid op zijn plaats is. ${ }^{28}$ Als relevante factoren voor het toetsen van de betrouwbaarheid worden door rechters benoemd: wordt de stemherkenning ondersteund door andere feiten en omstandigheden of bewijsmiddelen? Heeft de stemherkenning op ambtseed plaatsgevonden? Betwist de verdachte de stemherkenning? Is er sprake van stemherkenning door een persoon die de verdachte ook daadwerkelijk kent? Wat is de mate van zekerheid van de stemherkenning? Hoeveel uitgeluisterde gesprekken zijn er? Heeft de verdediging de mogelijkheid gehad om vragen te stellen over de wijze waarop de stemherkenning is gedaan en de wijze waarop de uitkomst daarvan in het dossier is gerelateerd ${ }^{29}$ Een bevoegdheid die aan alle kwaliteitseisen voldoet die door het EHRM worden gesteld, levert dus niet automatisch een betrouwbare uitkomst op.

Ook bij inbeslagneming en gegevensopneming is er geen sprake van een 'nieuwe' bevoegdheid maar van het niet achterlaten van het bewijs van de toepassing van de bevoegdheid. Hier komt het inderdaad aan op de motivering dat dit in het belang van het onderzoek dringend vereist is en dat dit bovendien wordt getoetst door de rechter-commissaris. De voorbeelden uit de memorie van toelichting overtuigen. In die situaties is er inderdaad sprake van een dringend (maatschappelijk) belang. Bovendien geldt (ook) hier de verplichting tot notificatie zodra het onderzoek dat toelaat. Die notificatie moet niet alleen de inzet van de bevoegdheid melden maar ook de resultaten ervan.

De voorgestelde regeling van de vijf bevoegdheden die als het nieuwe wetboek in werking is getreden ook heimelijk mogen worden toegepast, voldoen aan de eisen die door het EHRM aan een dergelijke regeling worden gesteld en aan een behoefte die in de opsporingspraktijk wordt gevoeld. Een op de wet gebaseerde opsporingspraktijk met een duidelijke normering is veruit te prevaleren boven een opsporingspraktijk die niet is gebaseerd op een specifieke wettelijke basis. Een wettelijke regeling van deze heimelijke bevoegdheden zoals voorgesteld is dan ook op zijn plaats. De echte uitdaging wordt de heimelijk toepassing van deze in beginsel openlijke bevoegdheden in de praktijk te beperken tot

27. Die bevindingen van het onderzoek kunnen zijn: ongeveer even waarschijnlijk; iets waarschijnlijker; waarschijnlijker; veel waarschijnlijker; zeer veel waarschijnlijker; extreem veel waarschijnlijker. Vakbijlage Vergelijkend handschriftonderzoek, NFI, 2015, p. 6.

28. Rb. Rotterdam 27 september 2007, ECLI:NL:RBROT:2007:BB4476; Rb. 's-Hertogenbosch 30 juni 2009, ECLI:NL:RBSHE:2009:BI9966; Rb. Gelderland 4 februari 2014, ECLI:NL:RBGEL:2014:1021; Rb. NoordHolland 19 juni 2019, ECLI:NL:RBNHO:2019:6223. Zie ook de conclusie van A-G Aben van 19 november 2019, ECLI:NL:PHR:2019:1183.

29. Rb. 's-Hertogenbosch 30 juni 2009, ECLI:NL:RBSHE:2009:BI9966 en Rb. Gelderland 4 februari 2014, ECLI:NL:RBGEL:2014:1021. 
die gevallen waarin de heimelijke toepassing daadwerkelijk noodzakelijk is. 